\title{
Prognosis and Predictive Factors according to Extent of Involvement in Necrotizing Enterocolitis among Very Low Birth Weight Infants
}

Ju Sun Heo, M.D., Young Hwa Jung, M.D., Juyoung Lee, M.D., Seung Han Shin, M.D., Ee-Kyung Kim, M.D., Han-Suk Kim, M.D., and Jung-Hwan Choi, M.D.

Department of Pediatrics, Seoul National University College of Medicine, Seoul, Korea

\section{ABSTRACT}

Purpose: This study aimed to evaluate the prognosis of necrotizing enterocolitis (NEC) according to the extent of involvement, among very low birth weight infants. Furthermore, the predictive factors for extent of involvement were evaluated.

Methods: Medical records of all newborns with surgically treated NEC admitted to the neonatal intensive care unit of Seoul National University Children's Hospital between 2005 and 2013 were reviewed. Infants were grouped according to the extent of involvement of NEC: isolated segment involvement (ISI, $n=31$ ) and multi-segment involvement (MSI, $\mathrm{n}=17$ ). We evaluated the clinical characteristics, outcomes, and pre-operative factors according to symptoms, laboratory and radiologic findings.

Results: The incidence of small for gestational age was significantly higher in the MSI than ISI group ( $12.9 \%$ vs. $41.2 \%, P=0.036)$. The length of resected bowel was significantly longer ( $1.7 \mathrm{~cm}$ vs. $8 \mathrm{~cm}, P=0.010$ ), and the incidence of short bowel syndrome (SBS) ( $0 \%$ vs. $23.1 \%, P=0.023)$ and mortality ( $3.2 \%$ vs. $23.5 \%, P=0.047)$ were significantly higher in the MSI than ISI group. However, there was no significant difference between the two groups in terms of high-output stoma, time of full enteral feeding, extrauterine growth retardation, changes of z-score of body weight between admission and discharge and reoperation. Portal vein gas detected by ultrasonography was the only statistically significant predictive factor of extent of involvement (odds ratio= 13.237, $P=0.029$ ).

Conclusion: SBS and mortality were higher in MSI NEC compared to ISI NEC. However, there was no difference in the time of full enteral feeding and growth between the two groups. Portal vein gas detected by ultrasonography maybe a predictive factor of extent of NEC.

Key Words: Necrotizing enterocolitis, Operation, Infant, Very low birth weight, Portal vein gas
Received: 28 January 2015

Revised: 24 February 2015

Accepted: 24 February 2015

Correspondence to:

Han-Suk Kim, M.D., Ph.D.

Department of Pediatrics, Seoul

National University College of Medicine, 103 Daehak-ro, Jongnogu, Seoul 110-799, Korea

Tel: +82-2-2072-1696

Fax: +82-2-743-3455, 747-5130

E-mail: kimhans@snu.ac.kr

Copyright(c)

By Korean Society of Neonatology.

All right reserved.

This is an Open-Access article distributed under the terms of the Creative Commons Attribution Non-Commercial License (http://creativecommons.org/licenses/ by-nc/3.0), which permits unrestricted non-commercial use, distribution, and reproduction in any medium, provided the original work is properly cited. 
서론

신생아 괴사성 장염은 신생아 중환자실에서 가장 흔하게 접할 수 있는 위장관계 응급 질환으로 ${ }^{1}$, 장 천공, 패혈증, 그리고 심각한 합병증 및 사망을 초래할 수 있다2,3) 신생아 괴사성 장염의 전체 발생 빈도는 약 1,000 명 생존아 당 1 명이지만 ${ }^{45}$, 출생 체중 1,500 $\mathrm{g}$ 미만의 극소저체중출생아에서는 그 빈도가 3-10\% 정도로 올라 가는 것으로 알려져 있다6,7). 최근 신생아 집중 치료술의 발달로 미숙아의 생존율이 향상됨에 따라 신생아 괴사성 장염의 발생 빈 도 또한 증가하는 양상을 보이고 있다8-10).

신생아 괴사성 장염으로 진단된 환자에서 내과적 치료에도 불 구하고 임상 소견이 악화될 때 또는 복강 내 유리 가스가 발생하 였을 때 수술적 치료를 시행하게 된다. 신생아 치료의 발전에도 불 구하고 신생아 괴사성 장염으로 진단된 환자의 약 20-40\%에서 수술적 치료를 필요로 한다 4,11 . 수술을 시행한 환자에서 수술 후 사망률과 밀접한 상관 관계를 갖는 요인으로 병변의 침범 범위를 언급한 기존의 논문들을 통해 공장을 함께 침범하거나 거의 전장 을 침범하는 경우 등이 불량한 예후 인자로 알려져 있다 ${ }^{22-15)}$. 전체 신생아 괴사성 장염의 사망률은 $15-30 \%$ 이지만 ${ }^{16)}$, 거의 전장을 침 범하는 진행된 신생아 괴사성 장염에서는 $90 \%$ 이상의 사망률을 보인다 ${ }^{1718)}$. 하지만 기존의 논문들은 모두 사망률에 대한 예후만 을 비교했을 뿐, 충분한 장관 영양 도달, 성장 등 다른 임상 결과에 대한 예후는 비교하지 않았다. 또한 광범위한 침범을 수술 전에 예 측할 수 있는 인자에 대해 언급한 논문은 없었다.

따라서 본 연구를 통해 침범 범위에 따른 다양한 임상 결과의 예후를 비교하고 광범위한 침범을 수술 전에 예측할 수 있는 인자 를 분석함으로써 신생아 괴사성 장염 환자의 치료 결정 및 예후 예측에 도움을 주고자 한다.

\section{대상 및 방법}

\section{1. 대상}

2005년 1월부터 2013년 12월까지 서울대학교 어린이병원의 신 생아집중치료실에 입원한 출생 체중 $1,500 \mathrm{~g}$ 미만의 극소저체중 출생아 중 신생아 괴사성 장염 진단 하에 수술적 치료를 받았고 수술장에서의 육안적 소견 및 병리 소견이 괴사성 장염에 합당한 48명을 대상으로 하였다. 수술은 (1) 집중적인 내과적 치료에도 불구하고 임상 양상, 검사실 소견 및 복부 방사선 소견이 악화되 는 경우, (2) 복부 X선 검사 또는 초음파에서 복강 내 유리 가스가 보이는 경우에 시행하였다.

\section{2. 방법}

신생아 괴사성 장염으로 수술받은 환자의 의무기록을 후향적 으로 고찰하였으며, 모든 데이터는 첫 번째 수술을 기준으로 수집 하였다. 소장 및 대장을 공장, 회장, 맹장, 결장, 직장으로 나누어 각 각을 하나의 분절로 보고, 하나의 분절만을 침범한 경우를 단일 분절 침범군, 2 개 이상의 분절을 침범한 경우를 다분절 침범군으 로 나누었다. 두 군간의 재태 주수, 성별, 출생 체중, 부당경량아 여 부, 퇴원시 체중 및 입원 기간 등 일반적 특성을 비교하였다. 부당 경량아는 연령 대비 출생 체중이 $10 \%$ 미만인 경우로 정의하였다. 수술과 관련된 요인으로 진단 시기, 수술 시기, 질병 기간(진단 후 수술 까지의 기간)을 비교하였으며, 진단 시기는 전신 증상, 장관 증상, 방사선학 소견으로 괴사성 장염을 의심하여 이에 대한 치료 를 시작한 시기로 정의하였다. 그 외에도 천공 여부, 절제한 장의 길이, 침범한 부위를 비교 분석하였다. 수술과 관련된 임상적 결과 로 단장증후군, 공장루, 과배출 장루, 수술 후 충분한 장관 영양 도 달 시기, 자궁외 성장 지연, 출생시와 퇴원시 사이의 체중의 $z^{-}$ score 변화, 재수술, 사망률을 조사하였다. 단장증후군은 수술 후 장 절제로 인한 흡수 장애가 발생하여 장기간 정맥 영양을 필요로 했던 경우로 정의하였으며19), 여기에는 절제 후 남아있는 장의 길 이가 짧은 경우 뿐 아니라 남아있는 장의 길이는 충분하더라도 장 루까지의 길이가 짧아 실질적으로 흡수를 담당하는 소장의 길이 가 짧은 경우도 포함하였다. 과배출 장루는 장루를 통해 하루에 $\mathrm{kg}$ 당 $30 \mathrm{~mL}$ 이상이 배액되는 경우로 정의하였다 ${ }^{20)}$. 자궁외 성장 지연은 퇴원 시점의 체중이 그 연령 대의 성장 곡선에서 $10 \%$ 미만 인 경우로 정의하였다. 출생시와 퇴원시의 체중 $z$-score는 2013 Fenton 성장 곡선 ${ }^{21}$ 을 기준으로 구하였으며 퇴원시 $Z$-score와 출 생시의 $z$-score의 차를 구하여 비교하였다. 재수술은 퇴원 전까 지 신생아 괴사성 장염 수술에 의한 합병증으로 추가적인 수술이 필요하였던 경우로 제한하였으며 단순한 장루 복원 수술은 배제 하였다. 단장증후군, 과배출 장루, 수술 후 충분한 장관 영양 도달 시기, 자궁외 성장 지연과 출생시와 퇴원시의 체중 $Z$-score 변화 는 생존한 환자만을 대상으로 비교하였다. 사망은 괴사성 장염으 로 인한 개복술과 연관이 있는 사망만을 포함하였다. 장 침범 범위 를 예측할 수 있는 지표를 확인하기 위해 임상 양상으로 복부 팽 만, 복부 색깔 변화, 저혈압 유무를 조사하였고, 혈액 검사 소견으 로는 수술 전까지 가장 나쁜 검사 소견을 기준으로 대사성 산증 $\left(\mathrm{pH}<7.25\right.$ 그리고 $\mathrm{HCO}_{3}<18 \mathrm{mmol} / \mathrm{L}$ 또는 Base excess<-4 $\mathrm{mmol} / \mathrm{L})$, 호흡성 산증 $\left(\mathrm{pH}<7.25\right.$ 그리고 $\mathrm{pCO}_{2}>50 \mathrm{mmHg}$ ) 유무, 가장 낮은 혈소판 수치 및 혈소판 수치의 감소 정도, 백혈구 수치 이상 $\left(>15,000\right.$ or $\left.<4,000 \times 10^{3} / \mu \mathrm{L}\right)$ 유무, C-반응성 단백 수치 및 $\mathrm{C}$-반응성 단백 수치의 이상 $(>1 \mathrm{mg} / \mathrm{dL})$ 유무를 조사하였다. 또한 복부 X선 검사 소견은 복강 내 장관 가스가 보이지 않는 경우, 장 폐색, 장벽 내 공기, 문맥 정맥 내 공기, 복강 내 유리 가스 여부를 
조사하였으며, 복부 초음파 소견은 장벽 비후, 장벽 내 공기, 문맥 정맥 내 공기, 복수, 복강 내 유리 가스 여부를 조사하였다. 방사선 소견은 영상의학과의 판독에 기초하였다.

\section{3. 통계학적 방법}

통계 분석은 SPSS Statistics, version 21 (SPSS Inc., Chicago, IL, USA)을 사용하여 연속 변수는 Student's t-test 또는 MannWhitney $U$ test로 비교하였으며, 독립 변수는 Pearson's chisquare test 또는 Fisher's exact test를 이용하였다. 연속 변수는 중앙값과 범위로 표시하였으며, 독립 변수는 퍼센트로 표시하였 다. $P$-value가 0.05 미만인 경우를 통계적으로 유의한 차이가 있 다고 판단하였다.

\section{결과}

\section{1. 괴사성 장염으로 수술 받은 환자의 일반적 특성}

괴사성 장염으로 수술 받은 환자의 재태 주수 중앙값은 단일 분절 침범군에서 $25^{+2}$ 주, 다분절 침범군에서 $27^{+0}$ 주로 다분절 침범 군에서 더 많기는 하였으나 두 군간 유의한 차이가 없었으며, 출생 체중은 단일 분절 침범군에서 $760 \mathrm{~g}(500-1,360 \mathrm{~g})$, 다분절 침범 군에서 $660 \mathrm{~g}$ (480-1,350 g)으로 이 또한 유의한 차이는 없었다. 하지만 부당경량아의 비율은 단일 분절 침범군에 비해 다분절 침 범군에서 유의하게 높았다( $12.9 \%$ vs. $41.2 \%, P=0.036)$. 부당경량 아 중에서 출생 체중이 5\% 미만인 경우와 5-10\%인 경우로 나누 어 비교했을 때, 다분절 침범군은 모두 5\% 미만의 심한 부당경량 아였던 반면, 단일 분절 침범군은 단 1명(25\%)만 $5 \%$ 미만에 해당 되었다 $(P=0.024)$. 그 외 성별, 원내 출생아 비율, 퇴원시의 체중, 입 원 기간에는 두 군간 유의한 차이가 없었다(Table 1).

Table 1. Clinical Characteristics of Patients

\begin{tabular}{lccc}
\hline & $\begin{array}{c}\text { Isolated segment } \\
(\mathrm{n}=31)\end{array}$ & $\begin{array}{c}\text { Multi-segment } \\
(\mathrm{n}=17)\end{array}$ & $\begin{array}{c}P \text { - } \\
\text { value }\end{array}$ \\
\hline Gestational age (wks) $^{*}$ & $25^{+2}\left(23^{+1}-30^{+5}\right)$ & $27^{+0}\left(23^{+1}-31^{+2}\right)$ & 0.101 \\
Birth weight (g)* $^{*}$ & $760(500-1,360)$ & $660(480-1,350)$ & 0.615 \\
Male $^{\dagger}$ & $20(64.5)$ & $12(70.6)$ & 0.670 \\
Inborn $^{\dagger}$ & $17(56.7)$ & $13(72.2)$ & 0.363 \\
SGA $^{\dagger}$ & $4(12.9)$ & $7(41.2)$ & 0.036 \\
Bwt at discharge (g)* $^{*}$ & $2,520(1,480-8,600)$ & $2,350(620-7,000)$ & 0.621 \\
Hospital stay (d)* & $112(39-416)$ & $118(10-264)$ & 0.399
\end{tabular}

*Values are median (range).

${ }^{\dagger}$ Values are number (\%).

Abbreviations: SGA, small for gestational age; Bwt, body weight.

\section{2. 단일 분절 침범군과 다분절 침범군의 수술과 관련된 특성}

진단 시기는 단일 분절 침범군에서 생후 8 일, 다분절 침범군에 서 생후 20 일로 다분절 침범군에서 유의하게 늦었으며 $(P=0.044)$, 수술 시기 또한 단일 분절 침범군이 생후 12 일인데 비해 다분절 침범군은 생후 24 일로 늦은 경향을 보였다 $(P=0.055)$. 하지만 질병 기간은 두 군 모두 3 일로 유의한 차이가 없었다. 수술의 적응증을 비교해 보았을 때, X선 검사 또는 초음파에서 복강 내 유리 가스 가 관찰되어 수술을 시행한 경우는 단일 분절 침범군에서 21 명 (67.7\%), 다분절 침범군에서 11명(64.7\%)으로 이 경우가 두 군 모 두에서 가장 높은 비율을 차지하였다. 그 외 고정된 장의 고리가 지속되어 수술을 시행한 경우는 단일 분절 침범군에서 2 명(6.5\%), 다분절 침범군에서 3 명(17.6\%)이었으며, 승압제에 반응없이 지속 되는 저혈압, 복부 팽만 악화, C-반응성 단백 및 혈소판 수치의 악 화로 수술을 시행한 경우는 단일 분절 침범군에서 8 명 $(25.8 \%)$, 다 분절 침범군에서 3 명 $(17.6 \%)$ 이었다. 수술 적응증에 대해 두 군 간 에 유의한 차이는 없었으며, 전체 환자 중 10 명을 제외한 나머지는 모두 진단 후 7일 이내에 수술을 시행받았다. 수술 소견 상 천공은 단일 분절 침범군에서 $71.0 \%$, 다분절 침범군에서 $76.5 \%$ 로 비슷 하게 존재하였다. 절제된 장의 길이는 단일 분절 침범군에서 1.7 $\mathrm{cm}(0-30.5 \mathrm{~cm})$, 다분절 침범군에서 $8 \mathrm{~cm}(0-70.0 \mathrm{~cm})$ 으로 다 분절 침범군에서 유의하게 길었다 $(P=0.010)$. 침범 부위를 보았을 때, 단일 분절 침범군에서는 회장, 공장 순으로 많았으며, 각각 $87.1 \%, 12.9 \%$ 였다. 대장, 회맹장 판막을 침범한 경우는 각각 1 명이 었다. 다분절 침범군에서는 공장과 회장 두 분절만을 동시에 침범 한 경우가 7명으로 가장 많았으며, 괴사가 광범위하게 진행하여 전장을 침범한 경우는 1 명이었다. 단일 분절 침범군과 다분절 침 범군을 비교하였을 때, 공장, 대장, 회맹장 판막의 침범 비율이 다

Table 2. Operation-Related Findings

\begin{tabular}{lccc}
\hline & $\begin{array}{c}\text { Isolated } \\
\text { segment } \\
(\mathrm{n}=31)\end{array}$ & $\begin{array}{c}\text { Multi- } \\
\text { segment } \\
(\mathrm{n}=17)\end{array}$ & $\begin{array}{c}P \text { - } \\
\text { value }\end{array}$ \\
\hline PND at onset of symptom* $^{*}$ & $8(1-41)$ & $20(2-45)$ & 0.044 \\
PND at operation* $^{*}$ & $12(2-44)$ & $24(4-89)$ & 0.055 \\
Duration of disease (d)* $^{*}$ & $3(0-26)$ & $3(1-56)$ & 0.193 \\
Perforation $^{\dagger}$ & $22(71.0)$ & $13(76.5)$ & 0.747 \\
Length of resected bowel (cm)* $^{*}$ & $1.7(0-30.5)$ & $8(0-70.0)$ & 0.010 \\
Site of involvement & & & \\
Jejunum $^{\dagger}$ & $4(12.9)$ & $9(52.9)$ & 0.006 \\
Ileum $^{\dagger}$ & $27(87.1)$ & $15(88.2)$ & 1.000 \\
Colon $^{\dagger}$ & $1(3.2)$ & $5(29.4)$ & 0.017 \\
Ileocecal valve $^{\dagger}$ & $1(3.2)$ & $6(35.3)$ & 0.005 \\
\hline
\end{tabular}

*Values are median (range).

†Values are number (\%).

Abbreviation: PND, postnatal day. 
분절 침범군에서 유의하게 높았다(Table 2).

\section{3. 단일 분절 침범군과 다분절 침범군의 수술과 관련된 임상 결과}

단장증후군은 단일 분절 침범군에서는 관찰되지 않았으며, 다 분절 침범군에서는 $23.1 \%$ 로 다분절 침범군에서 유의하게 많았다 $(P=0.023)$. 공장루의 비율은 단일 분절 침범군에서 $19.4 \%$, 다분절 침범군에서 $47.1 \%$ 로 다분절 침범군에서 유의하게 높았으나 $(P=$ $0.043)$, 과배출 장루( $23.3 \%$ vs. $46.2 \%, P=0.135)$ 의 비율은 두 군에 서 유의한 차이는 없었다. 충분한 장관 영양 도달 시기는 각각 수 술 후 26일(13-54일), 29일(5-273일)로 유의한 차이가 없었다. 자

Table 3. Operation-Related Clinical Outcomes

\begin{tabular}{lccc}
\hline & $\begin{array}{c}\text { Isolated segment } \\
(\mathrm{n}=31)\end{array}$ & $\begin{array}{c}\text { Multi-segment } \\
(\mathrm{n}=17)\end{array}$ & $\begin{array}{c}P \text { - } \\
\text { value }\end{array}$ \\
\hline SBS $^{\dagger}$ & $0 / 30(0.0)$ & $3 / 13(23.1)$ & 0.023 \\
Jejunostomy $^{\dagger}$ & $6(19.4)$ & $8(47.1)$ & 0.043 \\
HOS $^{\dagger}$ & $7 / 30(23.3)$ & $6 / 13(46.2)$ & 0.135 \\
POD reaching full & $26(13-54)$ & $29(5-273)$ & 0.198 \\
enteral feeding $^{*}$ & & & \\
EUGR $^{\dagger}$ & $23 / 30(76.7)$ & $10 / 13(76.9)$ & 1.000 \\
But $Z$-score change $^{*}$ & $-2.63(-5.46-0.39)$ & $-2.82(-4.79-0.18)$ & 0.781 \\
Reoperation $^{\dagger}$ & $9(29.0)$ & $5(29.4)$ & 0.978 \\
Mortality $^{\dagger}$ & $1(3.2)$ & $4(23.5)$ & 0.047 \\
\hline
\end{tabular}

*Values are median (range).

${ }^{\dagger}$ Values are number (\%).

Abbreviations: SBS, short bowel syndrome; HOS, high-output stoma; POD, post-operative days; EUGR, extrauterine growth retardation; Bwt, body weight.
궁외 성장 지연 비율은 두 군 모두 약 $76 \%$ 정도였으며, 출생시와 퇴원시의 체중 $z$-score 변화는 각각 -2.63 (-5.46-0.39), -2.82 (-4.79-0.18)로 유의한 차이는 없었다. 재수술 비율은 두 군 모두 $29 \%$ 정도로 유의한 차이는 없었다. 첫 번째 수술로부터 재수술까 지의 기간에 대한 중앙값은 단일 분절 침범군에서 48일(2-143일), 다분절 침범군에서 3 일(1-41일)로, 유의한 차이는 아니나 다분절 침범군에서 짧은 양상을 보였다 $(P=0.08)$. 단일 분절 증후군에서 는 수술 후 장관 협착(44.5\%), 장루 복원 전에 장루조영술 시행 중 발생한 천공(33.3\%)이 재수술의 주된 원인이었으나, 다분절 증후 군에서는 이 경우 외에도 수술 후 지속되는 장 출혈, 장 천공의 재 발, 장루의 괴사 진행으로 짧은 시간 간격으로 재수술을 시행받는 경우가 있었다. 사망률은 단일 분절 침범군에서 $3.2 \%$ (1명), 다분 절 침범군에서 $23.5 \%$ (4명)로 다분절 침범군에서 유의하게 높았 다 $(P=0.047)$. 단일 분절 침범군에서 사망한 환자는 수술 후 5 일 째에 패혈증과 함께 급성 호흡곤란 증후군으로 사망하였으며, 다 분절 침범군에서 사망한 환자들은 각각 수술 후 2 일, 4 일, 15 일 째 에 괴사성 장염 수술과 동반된 패혈증, 출혈, 다기관 기능 부전 등 으로 사망하였다(Table 3).

\section{4. 단일 분절 침범군과 다분절 침범군의 수술 전 임상 양상, 혈 액 검사 및 방사선 소견}

임상 양상과 관련해 복위 증가, 복부 색깔 변화, 저혈압은 두 군 간에 유의한 차이가 없었다. 혈액 검사에서 대사성 산증, 호흡성 산증의 비율은 유의한 차이가 없었으며, 가장 낮은 혈소판 수치는 단일 분절 침범군에서 $101 \times 10^{3} / \mu \mathrm{L}\left(13-274 \times 10^{3} / \mu \mathrm{L}\right)$, 다분절 침범 군에서 $53 \times 10^{3} / \mu \mathrm{L}\left(4-1,038 \times 10^{3} / \mu \mathrm{L}\right)$ 로 다분절 침범군에서 낮기

Table 4. Clinical Signs and Laboratory Findings

\begin{tabular}{|c|c|c|c|}
\hline & Isolated segment $(\mathrm{n}=31)$ & Multi-segment (n=17) & $P$-value \\
\hline$\overline{\mathrm{AC}}>1 \mathrm{~cm} / \mathrm{day}^{\dagger}$ & $27(87.1)$ & $15(88.2)$ & 1.000 \\
\hline Abdominal discoloration $^{\dagger}$ & $12(38.7)$ & $9(52.9)$ & 0.342 \\
\hline Hypotension $^{\dagger}$ & $16(51.6)$ & $9(52.9)$ & 0.930 \\
\hline Metabolic acidosis $^{\dagger}$ & $16(51.6)$ & $7(41.2)$ & 0.489 \\
\hline Respiratory acidosis $^{\dagger}$ & $17(54.8)$ & $9(52.9)$ & 0.900 \\
\hline Lowest PLT count $\left(10^{3} / \mu \mathrm{L}\right)$ & $101(13-274)$ & $53(4-1,038)$ & 0.852 \\
\hline PLT count $<100 \times 0^{3} / \mu \mathrm{L}^{\dagger}$ & $14(45.2)$ & $14(82.4)$ & 0.016 \\
\hline PLT decrease/day $\left(\times 10^{3} / \mu \mathrm{L}\right)^{*}$ & $33(0-90)$ & $37(0-135)$ & 0.143 \\
\hline PLT decrease $/$ day $>50 \times 10^{3} / \mu \mathrm{L}^{\dagger}$ & $9(29.0)$ & $7(41.2)$ & 0.393 \\
\hline WBC count $(/ \mu \mathrm{L})^{*}$ & $20,500(1,900-70,540)$ & $20,010(2,360-48,750)$ & 0.457 \\
\hline Abnormal WBC count ${ }^{\dagger}$ & $26(83.9)$ & $12(70.6)$ & 0.278 \\
\hline $\mathrm{CRP}(\mathrm{mg} / \mathrm{dL})^{*}$ & $1.15(0.02-23.89)$ & $0.81(0.01-36.99)$ & 0.498 \\
\hline $\mathrm{CRP}>1 \mathrm{mg} / \mathrm{dL}^{\dagger}$ & $16(51.6)$ & $7(41.2)$ & 0.489 \\
\hline
\end{tabular}

*Values are median (range).

${ }^{\dagger}$ Values are number (\%).

Abbreviations: AC, abdominal circumference; PLT, platelet; WBC, white blood cell; CRP, C-reactive protein. 
Table 5. Radiologic Findings

\begin{tabular}{lccr}
\hline & $\begin{array}{c}\text { Isolated segment } \\
(\mathrm{n}=31)\end{array}$ & $\begin{array}{c}\text { Multi-segment } \\
(\mathrm{n}=17)\end{array}$ & $\begin{array}{c}P \text { - } \\
\text { value }\end{array}$ \\
\hline X gasless abdomen & $2(6.5)$ & $0(0.0)$ & 0.533 \\
X ileus & $27(87.1)$ & $15(88.2)$ & 1.000 \\
X intramural gas & $1(3.2)$ & $2(11.8)$ & 0.283 \\
X portal vein gas & $0(0.0)$ & $1(5.9)$ & 0.354 \\
X free air & $16(51.6)$ & $8(47.1)$ & 0.763 \\
U bowel wall thickening & $10(32.3)$ & $10(58.8)$ & 0.074 \\
U intramural gas & $7(22.6)$ & $9(52.9)$ & 0.033 \\
U portal vein gas & $1(3.2)$ & $8(47.1)$ & $<0.001$ \\
U ascites & $16(51.6)$ & $14(82.4)$ & 0.060 \\
U free air & $5(16.1)$ & $3(17.6)$ & 1.000 \\
\hline
\end{tabular}

Values are number (\%).

Abbreviations: X, x-ray; U, ultrasonography.

는 하였으나 통계학적 유의성은 없었다. 하지만 혈소판 수치가 $100 \times 10^{3} / \mu \mathrm{L}$ 보다 낮은 비율은 단일 분절 침범군보다 다분절 침범 군에서 유의하게 높았다( $45.2 \%$ vs. $82.4 \%, P=0.016)$. 하루당 혈소 판 감소 수치 및 하루당 혈소판 감소 정도가 $50 \times 10^{3} / \mu \mathrm{L}$ 를 초과하 는 경우는 두 군간 유의한 차이는 없었다. 그 외 백혈구, C-반응성 단백에 대해서도 두 군간 통계학적 유의성은 없었다(Table 4).

복부 X선 검사에서 복강 내 장관 가스가 보이지 않는 경우, 장 폐색, 장벽 내 공기, 문맥 정맥 내 공기, 복강 내 유리 가스의 비율 은 모두 두 군간에 유의한 차이가 없었다. 복부 초음파 검사에서 장벽 비후, 복수 및 복강 내 유리 가스의 비율은 통계학적인 유의 성이 없었으나, 장벽 내 공기(22.6\% vs. $52.9 \%, P=0.033)$ 와 문맥 정 맥 내 공기(3.2\% vs. $47.1 \%, P<0.001)$ 의 비율은 모두 다분절 침범 군에서 유의하게 높았다(Table 5).

다분절 침범군을 예측할 수 있는 독립 인자를 찾기 위해 앞의 단변량 분석에서 통계학적 유의성을 가진 부당경량아, 가장 낮은 혈소판 수치가 $100 \times 10^{3} / \mu \mathrm{L}$ 미만인 경우, 복부 초음파의 장벽 내 공기 및 문맥 정맥 내 공기 소견에 대해 다변량 분석을 시행하였을 때, 복부 초음파의 문맥 정맥 내 공기 소견이 유일하게 통계학적으 로 유의하였으며 $(P=0.029)$, Odds ratio는 13.237이었다(Table 6). 이의 민감도는 $47.1 \%$, 특이도는 $96.8 \%$, 양성예측도는 $88.9 \%$, 음 성예측도는 $77.0 \%$ 였다.

\section{고찰}

본 연구를 통해 다분절 침범군이 단일 분절 침범군에 비해 단 장증후군과 사망률에 있어 불량한 예후를 보이지만, 그 외 충분한 장관 영양 도달 시기, 성장 등의 예후에 있어서는 차이가 없음을
Table 6. Adjusted Odds Ratios of Clinical Presentations for Prediction of Multi-Segment Involvement

\begin{tabular}{lcll}
\hline & $\begin{array}{c}\text { Adjusted } \\
\text { odds ratio }\end{array}$ & \multicolumn{1}{c}{$95 \% \mathrm{CI}$} & $P$-value \\
\hline SGA & 1.846 & $0.307-11.113$ & 0.503 \\
Lowest PLT $<100 \times 10^{3} / \mu \mathrm{L}$ & 3.432 & $0.680-17.330$ & 0.136 \\
U intramural gas & 2.041 & $0.424-9.828$ & 0.374 \\
U portal vein gas & 13.237 & $1.294-135.361$ & 0.029 \\
\hline
\end{tabular}

Abbreviations: CI, confidence interval; SGA, small for gestational age; PLT, platelet; U, ultrasonography.

확인하였다. 또한 복부 초음파의 문맥 정맥 내 공기 소견이 다분절 침범의 예측 인자가 될 수 있음을 제시하였다.

본 연구에서 비록 통계학적인 유의성은 없었으나 다분절 침범 군이 단일 분절 침범군에 비해 재태 주수는 큰 반면, 출생 체중은 적은 양상을 보였다. 이는 재태 주수 자체보다는 주수 대비 체중 이 적은 것이 침범 범위에 영향을 미칠 가능성이 큼을 시사하는 소견이다. 실제로 부당경량아의 비율을 비교하였을 때, 단일 분절 침범군보다 다분절 침범군에서 유의하게 높은 비율을 보였고, 부 당경량아 중에서도 자궁내 성장 지연 정도가 심할수록 더 넓은 범 위를 침범하는 괴사성 장염이 발생할 위험성이 큼을 알 수 있었다. 부당경량아는 산전 초음파에서 제대 동맥의 저항이 올라가고 이 완기 말 혈류가 소실되거나 역류되는 양상을 보이는 경우가 많다 ${ }^{22)}$. 이러한 경우 출생 전부터 뇌보호 효과를 위해 심박출량의 재분 배가 일어나 상장간막동맥의 혈류가 감소하게 되고23), 출생 이후 장혈류가 증가하더라도 이는 적정 체중아에 비해 더 낮은 수준을 보인달). 이를 통해 미성숙한 소장 및 대장에 불충분한 산소가 공급되고 장허혈 상태가 되면서 국소보다는 여러 분절에 걸친 넓 은 범위를 침범하는 신생아 괴사성 장염이 유발될 가능성이 클 것 으로 생각된다.

본 연구에서 단일 분절 침범군의 사망률은 $3.2 \%$, 다분절 침범 군의 사망률은 $23.5 \%$ 로 통계학적으로 유의하게 다분절 침범군의 사망률이 높았다. 이는 병변의 범위가 넓을수록 사망률이 높아진 다는 기존의 보고와 일치하는 소견으로 ${ }^{12,13)}$, 괴사된 장의 범위가 수술 후 사망률에 영향을 주는 유일한 인자라고 보고한 논문도 있 다 ${ }^{14)}$. 하지만 JO 등서의 논문에서 다국소 또는 전장을 침범한 경우 의 사망률이 $66.7 \%$ 인데 반해 본 연구에서는 $23.5 \%$ 로 낮은 소견 을 보였는데 이는 아마도 본 연구에서 전장을 침범한 경우가 단 1 명 뿐이었고 대부분 다국소 병변이었기 때문으로 생각되며, 실제 로 Fasoli 등12)의 연구에서 보고한 다국소 병변의 사망률 $30 \%$ 와 비슷한 비율을 보였다. 침범 부위에 따른 사망률을 비교했을 때, 공장을 포함하는 다분절 침범군은 $40.0 \%$, 그렇지 않은 경우는 $2.6 \%$ 로 두 군간에 유의한 차이를 보였다 $(P=0.005)$. 이를 통해 공 장을 포함한 다분절 침범의 경우 더 불량한 예후를 예측할 수 있 
으며, 이는 기존의 연구 결과와 일치하는 바이달)

단일 분절 침범군에 비해 다분절 침범군에서 절제된 장의 길 이가 유의하게 길고 단장증후군의 비율도 유의하게 높았으나 두 군간에 충분한 장관 영양 도달 시기, 자궁외 성장 지연 비율 및 출생시와 퇴원시의 체중의 $z$-score 변화에는 유의한 차이가 없 었다. 이는 남아있는 장의 절대적 길이 자체가 반드시 장의 소화 흡수 기능 및 성장과 연관이 있는 것이 아님을 시사하는 소견이 다. 장의 길이 외에도 환자의 나이, 남아있는 장의 부위, 대장의 존재 여부 등 여러 가지 요인들이 장의 소화 흡수 및 성장에 영향 을 줄 수 있다 ${ }^{19,25)}$. 또한 수술 이후 충분한 영양 공급 및 장적응 향상을 위한 의학적인 노력 또한 이에 영향을 미칠 수 있다. 실제 로 본 기관에서는 신생아와 소화기 의사, 영양사, 약사가 모인 다 분과 회의를 통해 환자들의 식이 진행 상태 및 영양 상태를 평가 하고 우유 성분 및 수유 방식의 변화, 약물 투여 등을 통해 장관 영양을 증가시킬 수 있는 방법을 도모한다. 또한 부족한 영양 성 분에 대한 정맥 영양의 조율을 통해 충분한 영양 공급이 이루어 지도록 하고 있다. 그리고 장루를 가지고 있는 환자에서 영양분 의 흡수, 점막 성장 자극, 장적응 촉진, 원위부 장의 위축 방지 목 적으로 근위부 장루로 나온 배액물을 원위부 장루로 넘겨주는 방식을 적용하고 있다 ${ }^{26)}$. 이러한 방법들이 충분한 장관 영양 도 달 및 성장에 긍정적인 영향을 주어 이와 연관된 두 군간의 임상 적 결과에 차이가 없었을 수 있겠다.

신생아 괴사성 장염의 침범 범위를 예측할 수 있는 독립적인 수 술 전 인자를 찾기 위해 단일 분절 침범군과 다분절 침범군 간에 유의한 차이가 있었던 부당경량아, 가장 낮은 혈소판 수치가 100 $\times 10^{3} / \mu \mathrm{L}$ 미만인 경우, 복부 초음파의 장벽 내 공기 및 문맥 정맥 내 공기 소견을 가지고 다변량 분석을 시행하였을 때, 초음파의 문 맥 정맥 내 공기 소견만이 통계학적으로 유의한 것으로 나왔다. 문 맥 정맥 내 공기는 장벽 내 공기가 장벽의 정맥을 통해 간문맥계로 들어와 관찰되는 소견으로 ${ }^{27)}$, X선 검사보다 초음파에서 더 잘 발 견되는 것으로 알려져 있다 ${ }^{28,29)}$. 신생아 괴사성 장염 환자에서 문 맥 정맥 내 공기 소견이 관찰될 때, 수술을 필요로 할 정도의 심한 상태로 진행한 것으로 여겨지며2730), 문맥 정맥 내 공기가 사망률 에 대한 유일한 방사선학적 예후인자라고 보고한 논문도 있다31). 하지만 문맥 정맥 내 공기 소견이 나쁜 예후와 연관되는 이유에 대 해 구체적으로 설명한 논문은 없다. 본 연구는 통계학적 방법을 통 해 문맥 정맥 내 공기 소견이 더 넓은 범위를 침범하는 수술적 소 견과 연관될 수 있음을 보임으로써, 이 것이 문맥 정맥 내 공기 소 견을 보이는 환자에서 예후가 나쁜 이유를 설명할 수 있는 한 가 지 논리가 될 수 있음을 처음으로 제시하는 바이다.

본 연구는 단일 3 차 기관에 입원하였던 극소저체중출생아 중 괴사성 장염으로 수술한 환자들을 대상으로 단일 분절 침범군과 다분절 침범군에서의 예후에 어떠한 차이가 있는지 알아보고자
하였고, 나아가 이러한 침범 범위와 연관될 수 있는 수술 전 예측 인자를 찾고자 하였다. 그러나 대상 환자의 수가 적고 후향적인 연 구로써 분석하고 해석하는데 제한점이 있었다. 또한 다국소 침범 과 전장 침범의 예후가 다를 수 있으나 전장 침범의 경우가 1 명 밖 에 없어 이를 독립된 군으로 구분하기 어려워 다분절 침범군에 포 함시켜 분석함으로써 침범 범위를 세분화하지 못한 한계가 있다. 하지만 본 연구를 통해 다분절 침범군이 단일 분절 침범군에 비해 단장증후군의 비율과 사망률이 높기는 하나 충분한 장관 영양 도 달, 성장에는 유의한 차이가 없었음을 확인하였다. 또한 복부 초음 파의 문맥 정맥 내 공기 소견이 다분절 침범을 예측하는 독립 인 자가 될 수 있음을 제시하였다. 따라서 초음파 상 문맥 정맥 내 공 기 소견이 관찰될 때 좀더 주의 깊은 경과 관찰과 함께 적극적인 내과적 또는 외과적 치료를 고려할 필요가 있겠다. 또한 앞서 언급 한 영양 지원을 위한 다분과 회의 및 장루 넘겨주기 방식 등이 구 체적으로 성장 및 장적응에 어떤 도움을 주는지에 대한 추가적인 연구가 필요하다.

\section{REFERENCES}

1) Pierro A, Hall N. Surgical treatments of infants with necrotizing enterocolitis. Semin Neonatol 2003;8:223-32.

2) Kliegman RM, Fanaroff AA. Necrotizing enterocolitis. N Engl J Med 1984;310:1093-103.

3) Narang A, Rao R, Bhakoo ON. Neonatal necrotizing enterocolitis an epidemiological study. Indian Pediatr 1993;30:120714.

4) Holman RC, Stoll BJ, Curns AT, Yorita KL, Steiner CA, Schonberger LB. Necrotising enterocolitis hospitalisations among neonates in the United States. Paediatr Perinat Epidemiol 2006; 20:498-506.

5) Llanos AR, Moss ME, Pinzòn MC, Dye T, Sinkin RA, Kendig JW. Epidemiology of neonatal necrotising enterocolitis: a population-based study. Paediatr Perinat Epidemiol 2002;16:342-9.

6) Kim MJ, Ahn SY, Choi SY, Park JH, Lee MS, Sung SI, et al. Operational outcomes of bowel perforation due to necrotizing enterocolitis in preterm infants of less than or equal to 25 weeks' gestational age. Neonatal Med 2013;20:438-46.

7) Srinivasan PS, Brandler MD, D'Souza A. Necrotizing enterocolitis. Clin Perinatol 2008;35:251-72.

8) Hwang JH, Choi CW, Chang JY, Park WS. Epidemiology of neonatal necrotizing enterocolitis: a 8-year experience. J Korean Soc Neonatol 2003;10:178-84.

9) Petrosyan M, Guner YS, Williams M, Grishin A, Ford HR. Current concepts regarding the pathogenesis of necrotizing enterocolitis. Pediatr Surg Int 2009;25:309-18. 
10) Ford HR. Mechanism of nitric oxide-mediated intestinal barrier failure: insight into the pathogenesis of necrotizing enterocolitis. J Pediatr Surg 2006;41:294-9.

11) Blakely ML, Gupta H, Lally KP. Surgical management of necrotizing enterocolitis and isolated intestinal perforation in premature neonates. Semin Perinatol 2008;32:122-6.

12) Fasoli L, Turi RA, Spitz L, Kiely EM, Drake D, Pierro A. Necrotizing enterocolitis: extent of disease and surgical treatment. J Pediatr Surg 1999;34:1096-9.

13) de Souza JC, Fraga JC. Is mortality rate influenced by the site of involvement in neonates undergoing laparotomy for necrotizing enterocolitis? J Pediatr Surg 2009;44:1534-9.

14) Jo HJ, Cho $\mathrm{YH}$, Kim HY. Clinical factors affecting postoperative mortality in necrotizing enterocolitis. J Korean Surg Soc 2006; 70:390-5.

15) Pierro A. The surgical management of necrotising enterocolitis. Early Hum Dev 2005;81:79-85.

16) Dominguez KM, Moss RL. Necrotizing enterocolitis. Clin Perinatol 2012;39:387-401.

17) Lambert DK, Christensen RD, Baer VL, Henry E, Gordon PV, Besner GE, et al. Fulminant necrotizing enterocolitis in a multihospital healthcare system. J Perinatol 2012;32:194-8.

18) Henry MC, Lawrence Moss R. Surgical therapy for necrotizing enterocolitis: bringing evidence to the bedside. Semin Pediatr Surg 2005;14:181-90.

19) Wales PW, Christison-Lagay ER. Short bowel syndrome: epidemiology and etiology. Semin Pediatr Surg 2010;19:3-9.

20) Soldes OS. Ileostomy and colostomy. In: Mattei P, editor. Fundamentals of pediatric surgery. Philadelphia: Springer, 2011: 447.

21) Fenton TR, Kim JH. A systematic review and meta-analysis to revise the Fenton growth chart for preterm infants. BMC Pediatr 2013;13:59.
22) Arbeille P. Fetal arterial Doppler-IUGR and hypoxia. E J Obstet Gynecol Reprod Biol 1997;75:51-3.

23) Dubiel M, Breborowicz GH, Gudmundsson S. Evaluation of fetal circulation redistribution in pregnancies with absent or reversed diastolic flow in the umbilical artery. Early Hum Dev 2003;71:149-56.

24) Maruyama K, Koizumi T. Superior mesenteric artery blood flow velocity in small for gestational age infants of very low birth weight during the early neonatal period. J Perinat Med 2001; 29:64-70.

25) Weseman RA, Gilroy R. Nutrition management of small bowel transplant patients. Nutr Clin Pract 2005;20:509-16.

26) Richardson $L$, Banerjee $S$, Rabe $H$. What is the evidence on the practice of mucous fistula refeeding in neonates with short bowel syndrome? J Pediatr Gastroenterol Nutr 2006;43:267-70.

27) Epelman M, Daneman A, Navarro OM, Morag I, Moore AM, Kim JH, et al. Necrotizing enterocolitis: review of state-of-theart imaging findings with pathologic correlation. Radiographics 2007;27:285-305.

28) Bohnhorst B. Usefulness of abdominal ultrasound in diagnosing necrotising enterocolitis. Arch Dis Child Fetal Neonatal Ed 2013;98:F445-50.

29) Bömelburg $T$, von Lengerke $H J$. Sonographic findings in infants with suspected necrotizing enterocolitis. Eur J Radiol 1992; 15:149-53.

30) Coursey CA, Hollingsworth CL, Wriston C, Beam C, Rice H, Bisset $\mathrm{G}$ 3rd. Radiographic predictors of disease severity in neonates and infants with necrotizing enterocolitis. AJR Am J Roentgenol 2009;193:1408-13.

31) Cikrit D, Mastandrea J, West KW, Schreiner RL, Grosfeld JL. Necrotizing enterocolitis: factors affecting mortality in 101 surgical cases. Surgery 1984;96:648-55. 